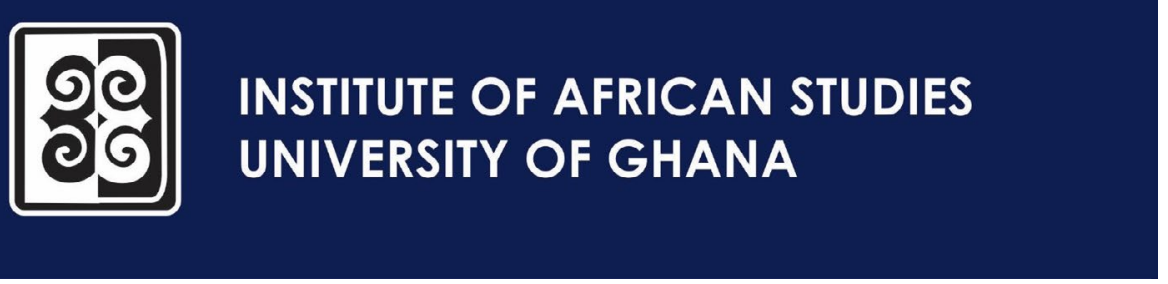

Contemporary Journal of African Studies 2020; 7 (1): 97-115

https://dx.doi.org/10.4314/contjas.v7i1.7

ISSN 2343-6530

(C) 2020 The Author(s)

Open Access article distributed under the terms of the

Creative Commons License [CC BY-NC-ND 4.0]

http://creativecommons.org/licenses/by-nc-nd/4.0

\title{
The restitution debate and return of human remains: implications for bioarchaeological research and cultural ethics in Africa
}

\section{Pearl Lamptey ${ }^{1} \&$ Wazi Apoh $^{2}$}

${ }^{\prime}$ Graduate student/research assistant, Department of Archaeology and Heritage Studies, University of Ghana. Author email: pearllamptey42@gmail.com

${ }^{2}$ Associate Professor, Department of Archaeology and Heritage Studies, University of Ghana.Authoremail: wapoh@ug.edu.gh

\section{Abstract}

The calls for repatriation and restitution of African objects and human remains in unlawful Euroamerican custody are gaining global momentum. This paper examines how bioarchaeological analyses are done on legitimately excavated or acquired human remains. Such studies are assessed in tandem with the negative eugenicist practices associated with the looted African human remains that were studied in Europe and America during the periods of slavery and colonization in Africa. It further examines the issues surrounding the repatriation of human remains and discusses the implications of this practice on the ethics and cultural rights of societies in Africa. Excavated human skeletal remains from Begho are examined within their cultural context as a Ghanaian case study. By exploring these issues, we are of the view that the complexities in the nature of acquisition and return of human remains requires a holistic comprehension from multiple points of view rather than from a single subjective perspective. Such multiple approaches must include the need for adequate provenance and bioarchaeological research to bear on the contexts and practices associated with the anthropology of death in the societies of origin.

Keywords: Repatriation, bioarchaeology, restitution, human remains, bio-history, archaeological record 
The Restitution Debate and Return of Human Remains: Implications for Bioarchaeological Research and Cultural Ethics in Africa

\author{
Pearl Lamptey and Wazi Apoh
}

\begin{abstract}
The calls for repatriation and restitution of African objects and human remains in unlawful Euroamerican custody are gaining global momentum. This paper examines how bioarchaeological analyses are done on legitimately excavated or acquired human remains. Such studies are assessed in tandem with the negative eugenicist practices associated with the looted African Human remains that were studied in Europe and America during the periods of slavery and colonization in Africa. It further examines the issues surrounding the repatriation of human remains and discusses the implications of this practice on the ethics and cultural rights of societies in Africa. Excavated human skeletal remains from Begho are examined within their cultural context as a Ghanaian case study. By exploring these issues, we are of the view that the complexities in the nature of acquisition and return of human remains requires a holistic comprehension from multiple points of view rather than from a single subjective perspective. Such multiple approaches must include the need for adequate provenance and bioarchaeological research to bear on the contexts and practices associated with the anthropology of death in the societies of origin.
\end{abstract}

Keywords: Repatriation, Bioarchaeology, Restitution, Human remains, Bio-history, Archaeological record.

\title{
https://dx.doi.org/10.4314/contias.v7i1.7
}

Ms. Pearl S.N.O. Lamptey (pearllamptey42@gmail.com) is a Graduate Student/ Research Assistant at the Department of Archaeology and Heritage Studies, University of Ghana. Ms. Lamptey has handled the tutorial sessions of four undergraduate courses and participated in a number of Archaeological Field Projects organized by the Department from 2016 to date. Her research focuses on the application of bioarchaeology in understanding Ghana's past. She is a recipient of the Andrew W. Mellon- Enhancing Doctoral Training (ENDoTH-UG) fellowship in the Humanities, University of Ghana. 


\section{Résumé}

Les appels au rapatriement et à la restitution d' objets et de restes humains africains détenus illégalement par les Euro-Américains gagnent du terrain dans le monde entier. Cet article examine la manière dont les analyses bioarchéologiques sont effectuées sur des restes humains légitimement fouillés ou acquis. Ces études sont évaluées en tandem avec les pratiques eugénistes négatives associées aux restes humains africains pillés qui ont été étudiés en Europe et en Amérique pendant les périodes d'esclavage et de colonisation en Afrique. Il examine en outre les questions entourant le rapatriement des restes humains et discute des implications de cette pratique sur l' éthique et les droits culturels des sociétés en Afrique. Les restes humains exhumés de Begho sont examinés dans leur contexte culturel comme une étude de cas ghanéenne. En explorant ces questions, nous sommes d'avis que la complexité de la nature de l' acquisition et de la restitution des restes humains exige une compréhension holistique à partir de multiples points de vue plutôt que d'une seule perspective subjective. Ces approches multiples doivent inclure la nécessité d'une provenance adéquate et d' une recherche bioarchéologique qui porte sur les contextes et les pratiques associés à l' anthropologie de la mort dans les sociétés d' origine.

Mots clés: Rapatriement, Bioarchéologie, Restitution, Restes humains, Bio-histoire, Dossier archéologique.

\section{Introduction}

Restitution and repatriation are terms which refer to the return of objects and human remains to their places or countries of origin; reparation, on the other hand, is the process of compensating for the loss of material culture or objects taken from a society or country without permission. Both restitution and repatriation debates have mainly centered on ownership of objects, medium of acquisition, negotiations and how returns are to proceed.

Two levels of repatriation, especially of human remains, defined on intra and inter country basis exist. Indigenous repatriation is the return of objects within the country, particularly, from state museums and universities to their communities of origin. For example, over the years Australia has developed an Indigenous repatriation program to prohibit the exportation of Aboriginal \& Torres Strait Islander ancestral remains and sacred objects. ${ }^{1}$ In addition, the Australian Indigenous Repatriation Museum Grants Program has enabled about 2,500 ancestral remains and over 2,200 secret sacred objects collected from communities in the past and held or exhibited in state museums, to be returned to the custodianship of the various communities of origin. ${ }^{2}$

\footnotetext{
${ }^{1}$ Indigenous Restitution. https://www.arts.gov.au/what-we-do/cultural-heritage/indigenous-repatriation. Retrieved 15 November 2019.

2 Domestic Repatriation. https://www.arts.gov.au/what-we-do/cultural-heritage/indigenous-repatriation/ domestic-repatriation. Retrieved 15/11/2019.
} 
Inter country repatriation, as its name suggests, is the return of objects from overseas to their countries of origin. For example, on 28 November 2019, Germany's State Ethnographic Collections of Saxony returned the remains of 45 indigenous Australians to Australia in a moving handover ceremony at the Grassi Museum in Leipzig. ${ }^{3}$ Eight years earlier, Germany, which has the largest concentration of museums holding Africa cultural resources/treasures and human bones, had returned 20 skulls to the Namibian Embassy in Berlin. The skulls belonged to the Herero and Nama people, and had been illegally acquired mostly from the Shark Island, Windhoek Concentration Camp and Rehoboth site over time in Namibia and used as eugenicist laboratory research samples to classify race and to validate the erroneous belief in the alleged physical inferiority and backwardness of Africans (Erichsen, 2005; Selden, 1999). Eugenics as a "science" advocated "the selective breeding of human populations (including forced sterilisations) to improve the gene-pool" and was promoted by many secular thinkers of the nineteenth and early twentieth centuries in the name of science, reason, and progress (Balogh, 2019; Fischer, 1959). Consequently, the use of all manner of skulls and human skeletal remains to validate conflicting findings was common during this time.

One unique example of inter country repatriation in West Africa is the Dutch government's return of the severed head of the Ahanta King Badu Bonsu II in 2009 after being left forgotten in the laboratory closets of Leiden Hospital University Centre since the 1830s. The implications of this have been fully examined by Dzidzienyo and Nkumbaan in this volume. A number of calls for the return of African human remains in Europe are yet to be heeded such as the incessant demand made by the late Zimbabwean president Robert Mugabe for the return of the skulls of a group of revolutionaries who were killed and decapitated by British colonizers in the late nineteenth century. Mugabe noted at a Heroes Day commemoration in Harare that, "...surely keeping decapitated heads as war trophies, in this day and age, in [the London] Natural History Museum, must rank among the highest forms of racist moral decadence, sadism and human insensitivity." 4

The million-dollar question, of course, is why the human skulls of Africans were so "treasured" by European museums and laboratories and acquired without any humane sensitivity attached to them? How many of Africa's human skeletal remains and tissues are still immorally held in European museums and laboratories? The ways by which most of them were acquired and sent to Europe for eugenicist studies were illegitimate and inhumane (Jacoby \& Glauberman, 1995). There were instances where the colonizers and skull hunters targeted people with particular skull shapes and sizes and killed them in cold blood just to harvest their skulls for

\footnotetext{
${ }^{3}$ Australian Indigenous ancestors returned home to Australia. https://www.arts.gov.au/departmentalnews/australian-indigenous-ancestors-returned-home-australia. Retrieved 29/11/2019.

${ }^{4}$ Robert Mugabe tells Natural History Museum to return human skulls. https://www.theguardian.com/ world/2015/aug/13/mugabe-demands-return-of-skulls-from-londons-natural-history-museum Retrieved May 5, 2019.
} 
European scientific study. Some skull hunters desecrated graves to loot human skulls and skeletons, thus denying the deceased peaceful rest and promoting a spiritual disconnection with their descendants. Other colonizers deliberately starved victims to death only to harvest their skulls later (Erichsen \& Olusoga, 2010: 219). Colonial agents also "disappeared" other victims on the pretense that they were being isolated from the communities for having contagious and noncontagious diseases (Apoh, 2019). These skulls are now in European museums, having been stripped of their individuality and humanity and replaced with labels and code numbers.

Unfortunately, the findings accrued from these examinations of human skulls, illegitimately acquired in conditions of asymmetrical power relations, were regarded as scientific breakthroughs from the late 1800s into the early twentieth century. With knowledge of how these remains were heinously collected and dehumanized, can we accept or validate any scientific deductions based on them? Are these conclusions on par with some scientific studies of legitimately acquired human remains that have been lauded and accepted as standard scientific procedures whose outcomes have tended to help us understand the past in meaningful ways? These are some of the questions of concern in the realm of bioarchaeological studies. This paper explores this legitimate way of studying human skeletal remains. It also assesses its implication as an investigative tool for provenance studies and method of assessment of skeletons that are to be returned to their countries of origin.

\section{Human Remains and Bioarchaeological Studies}

Finding human skeletons in museums and laboratories principally suggests they were acquired to be subjected to scientific study. That in itself is not a big problem especially if they were acquired under legitimate and permitted conditions such as an archaeological excavation site, relocating graveyards or when they are accidentally exhumed by erosion or by construction activities. The study of legitimately acquired human skeletons falls under various related disciplines such as physical anthropology, skeletal biology, anatomy and bioarchaeology.

Skeletal remains form part of tangible remains and are often classified as biofacts within the archaeological record. Most of what is known about past and recent histories of humans are predominantly based on inferences derived from the analysis of artefacts, ecofacts, documents, oral histories, and other products of human cultural activities (Walker, 2000); often to the neglect of human skeletons. As a sub-discipline of archaeology, bioarchaeology refers to the study of biological remains (human, plant and animal) within their cultural (archaeological) contexts in order to solve physical anthropological questions (Killgrove, 2013: 1). The term bioarchaeology was first coined in 1972 by the British archaeologist, Graham Clark, and he applied it to his study of faunal remains at Star Carr in Yorkshire, England. He later defined 'bioarchaeology' as “the archaeology concerned first 
and foremost with life" and as "the archaeology of how [humans] occupied territories and maintained life" (Clark 1973). This is related to how humans adapted to environmental factors with ideas and tools of culture. These factors over time affect the morphology and development of the human skeleton, which become evident on the bones after death and decomposition of soft tissues.

Bioarchaeological practices may be employed in medico-legal cases and can aid in forensic investigations associated with human skeletons. Similarly, it can be used to assess restituted human remains or human elements attached to other materials like drums and horns. In combining methods and theories in archaeology, biology, chemistry, history and demography, among others, bioarchaeologists bring to the fore an eclectic and a multidisciplinary perspective to revealing bio-history and understanding the lifeways of humanity.

As introduced above, the quest for the study of modern human skeletons among Euroamerican scientists, launched a frenzied practice that included the collection of human skeletons; especially those from the colonies. By the second half of the $19^{\text {th }}$ century, the field of physical anthropology was recognized in Europe with early key practitioners as Paul Broca, a surgeon in France and Rudolf Virchow, a physician and anatomist in Germany. They advanced research on the study of human remains (Roberts, 2009: 6-7). In Britain, for instance, early works on physical anthropology concentrated on measuring bones, including skulls (Roberts, 2009: 7). According to Roberts (2009: 7), considerable interest in the study of skulls developed over the course of the $19^{\text {th }}$ century with works of Davis and Thurman (1865). Even though much of the works or studies on skulls took unethical directions under the eugenicist discourse, there were some very real advances (Roberts, 2009: 7). Researchers like Karl Pearson took a statistical approach in examining large samples and exploring the belief that evolution progressed by small continuous variations (Stephan, 1982).

Refined in the United States as a scientific study, Jane Buikstra, in 1977 , viewed bioarchaeology as a concept and a practice focused on the study of human skeletal remains from archaeological sites. To Buikstra, bioarchaeology is a multidisciplinary research approach that addresses archaeothanatological questions of burials, social organization, behavior and activities, paleodemography, population interaction, diet and disease (see also Duday, 2009). Thus, bioarchaeology as a multidisciplinary science, draws on methods in other disciplines (Larsen, 2000: 1-2). This collaboration contributes to a broader and more informed perspective on the complexities associated with the study of skeletons as well as the past. Bioarchaeologists apply the study of stable isotopes in bone tissues to reconstruct diet. They extract DNA from bone samples to help identify population histories and use developing and advanced technology, such as scanning electron microscopy and computer axial tomography (CAT or CT scans) to identify bone shape and tooth use. They also conduct histological studies/ analyses on teeth and bone to reveal 
age. Above all, they are able to analyze microscopic sections of bones and teeth to diagnose ancient diseases and DNA connections to descendant communities.

According to Larsen (1997: 2-3), central to bioarchaeological enquiry is the determination of the relationship that exists between biology and behavior. In this regard, scholars regard "the body as the nexus between biology and culture" (Sofaer, 2006: 30). According to Rubalcaba and Robertshaw (2010: 1), most people think the dead are silent, but to an archaeologist, the dead are boisterous storytellers who continue to reveal narratives about the lives and lifestyles of people and societies from hundreds, thousands and millions of years ago. Additionally, the data gleaned from skeletal studies are of great value. For example, the human skeleton, specifically bones and teeth, record conditions of growth and development as mirrored in factors of stress, activity and injury, climate, disease, diet and nutrition (Larsen, 2000). The more varied the evidences we have about the past, the more convincing our interpretations can be. This can be done by using a series of data sources open to eclectic interpretations to triangulate and reconstruct what really happened in the past. This approach is indeed needed to conduct provenance research on controversial skeletal remains that are under consideration for restitution and return.

It is notable that human remains, whether in their buried state or analytical state in the laboratory, are subject to taphonomic processes or transformation over time. These include the impact of acidic soils and termites, which can reduce the elements and insights that can be gleaned from them to aid in the understanding of the archaeological record. They are also often coated with poisonous anti insect chemicals in the museums and labs to conserve them. Hodder $(1987,1992,1999)$ asserts that the structure of the archaeological record is crucial to archaeological interpretation and understandings of past behavioural dynamics. That is why much documentation of the excavation process and contextual information of finds are needed to aid in post field analyses and interpretation. Unfortunately, this is not the case with looted skulls in European museums or unscientifically excavated skeletons that find their way into laboratories. The ensuing section of this paper looks at a case study in respect to the skeletons from Hani-Begho in Ghana in view of the above consideration.

\section{Bioarchaeology of Hani-Begho Human Remains and Implications for Assessing Returned Remains}

Some skeletons from Begho (Fig 1) were subjected to bioarchaeological analysis in $2018^{5}$. The research samples included a number of fragmentary and complete skeletal elements from buried people of Begho. The available associated

\footnotetext{
${ }^{5}$ This research was carried out by Pearl Lamptey under the supervision of Prof Wazi Apoh. Findings are available in "Contributions of Bioarchaeology to Understanding the Past: A Study of Excavated Human Skeletons from Hani-Begho, Ghana." Unpublished Master's Thesis. Department of Archaeology and Heritage Studies. University of Ghana. Accra, Ghana. (2018).
} 
records are not clear on how they were obtained from different quarters within the Begho site by various scholars from the Department of Archaeology and Heritage Studies in the 1970s. According to Posnansky (2015:96), Begho could have been the largest town in the interior of the Gold Coast in 1471 when the Portuguese arrived on the coast and that "between the $13^{\text {th }}$ and $15^{\text {th }}$ centuries, Begho was either a cultural entity or a city-state." It was also one of the market centers that served the Trans-Saharan Trade in the medieval period. Research conducted on the site in the 1970s unearthed tobacco pipe bowls and stems, pottery, fauna, findings of copper wire and other fragments that have been dated from the 11th to the 17th centuries AD (Anquandah, 1995; Delafosse, 1904; Ozanne, 1965; Pearson, 1961; Posnansky, 1970, 2004, 2015: 98; Meyerowitz, 1952).

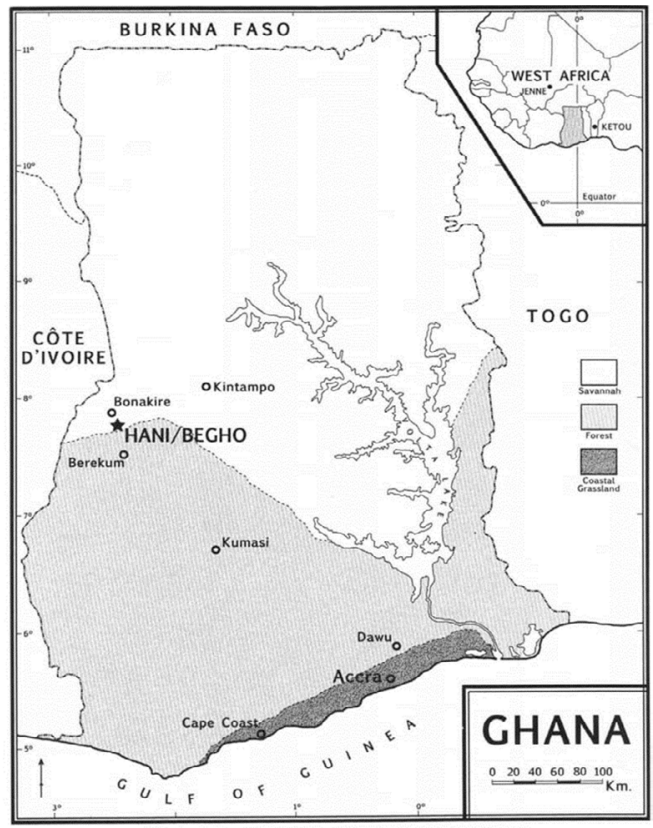

Fig 1. Map of the Ghana showing the study area of Hani-Begho

(Posnanky, 2015)

Still, a bioarchaeological study of the skeletons from Begho that have been sitting in the closet of the Museum of Archaeology, University of Ghana since the 1970s without analysis or sent abroad by the scholars without available traces (see Figs 2 and 3), was also necessary to excavate the 'memory' and 'voice' (Larsen, 2000) of Begho's past.

This preliminary analysis carried out in the Department of Archaeology and Heritage Studies was insightful (Lamptey 2018). Firstly, the use of standard qualitative and quantitative analyses on the skeletons were done to elicit data and understandings of their biohistories ranging from sex, age, stature, antemortem and peri-mortem trauma/pathology and dental health as well as dietary 
patterns. Further research was done to document the ethnographic and current anthropological practices that are associated with death (archaeothanathology) in the Hani-Begho descendant community area to understand some associated contextual cultural behaviors and activities that are often not available with such laboratory skeletons.

Through the analysis of the Begho remains, it came to light that cases of antemortem teeth loss among the elderly were prevalent in the Begho community. Teeth loss could have resulted from degenerative changes that occur in people as they grow. It could also be attributed to the willing removal of teeth by people suffering from extensive/recurrent caries as a way of easing the discomfort that comes with it or from accidental fall or blunt force trauma. Since these happened while the person was alive, some sort of healing in the form of bone growth seals up the sockets in the gum.

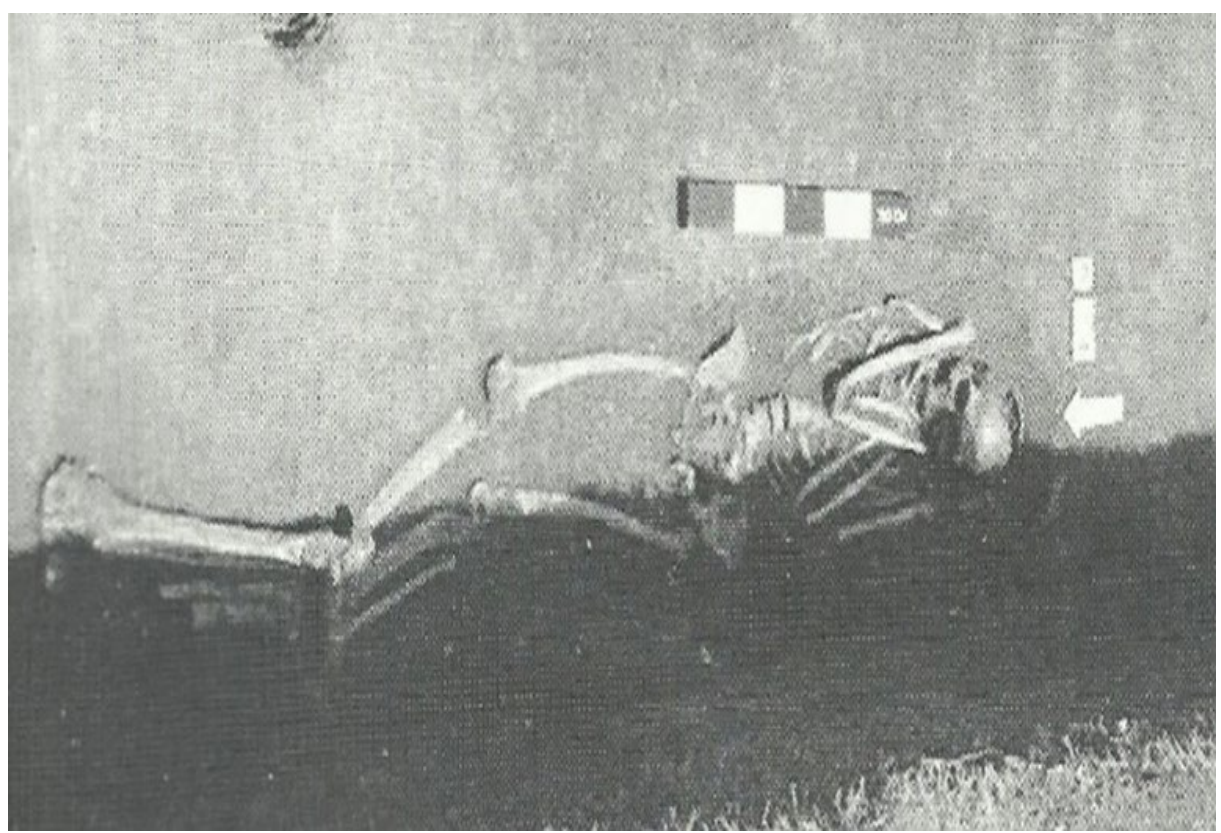

Fig. 2 Skeleton lying in a dorsal view during the excavation of the K1 Kramo quarter site of Begho in 1970 (Source: Posnansky, 2010). 


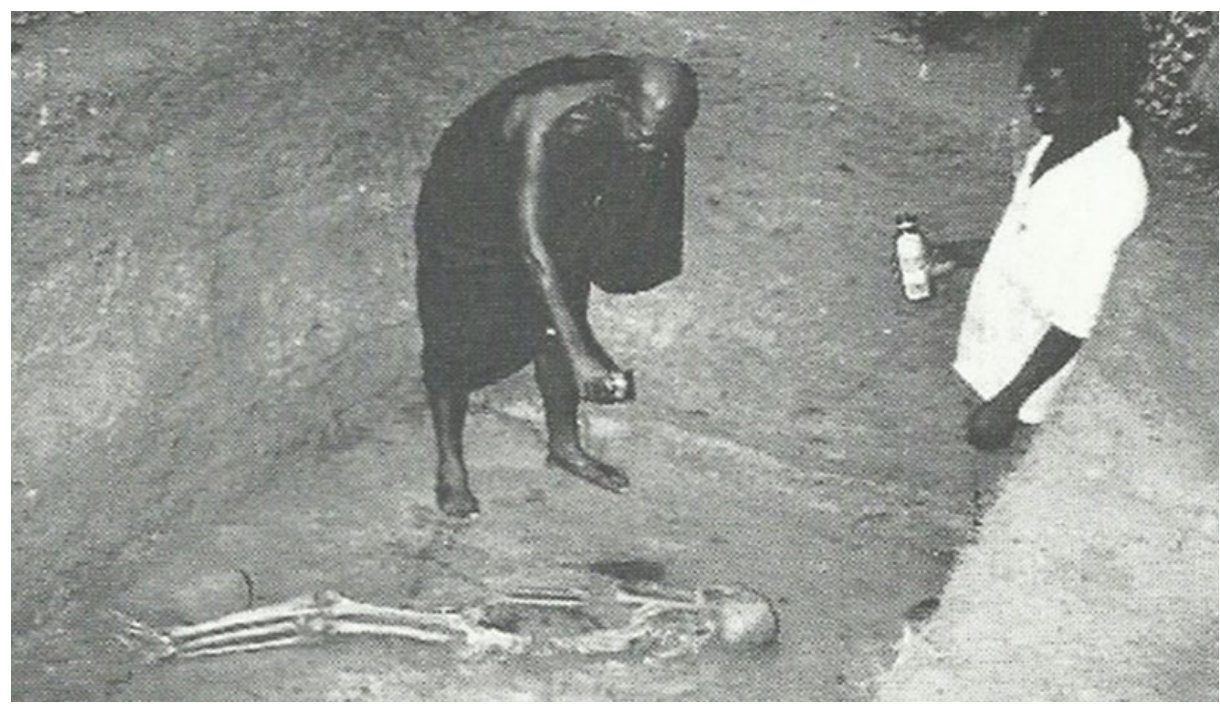

Fig. 3 The Hanihene pouring libations before removal of skeleton. No grave goods were found but the skeleton represents a respected member of the community buried beneath a house floor (Source: Posnansky, 2010).

This explained the empty spaces of the molars and premolars evident on some of the mandibular and maxilla regions of the Begho skulls (see Fig 4). Also evident in the dental arcade of all skeletal samples from Begho were extensive wears on the occlusal surfaces of the cusps or enamels of the teeth, otherwise referred to as occlusal wear. Such wears occur from masticatory behavior. What we eat and how we chew what we eat have lifelong consequences on our dentition. Moreover, cases of caries and dental calculus can change enamel surfaces over time and occasionally break parts of the teeth.

Occlusal wear analysis could provide insights into grain and food types such as kola nuts or rice with sand grains exploited in the diet of the Begho people in the past. Documented literature reveals that the people of Begho were farmers (see Posnansky, 1970, 2015). The contemporary populations of the community are also predominantly farmers. Hence it can be concluded that aside from degenerative factors such as old age that cause lipping, which have been identified on the vertebrae of the Begho skeletons, lipping on the vertebrates could also be caused by stress and occupational pressures/ hazards such as farming and food processing activities exerted on the vertebral elements of the people through time (Lamptey, 2018: 95-96).

Naturally, some people, due to genetic factors can have small-sized teeth and diastema in-between their incisors. However, the ethnographic study and documentation of oral history in Hani have revealed that until recently diastema development in-between either the upper or lower incisors or both were regarded as a mark of beauty. As such, if people were born without it, they were considered 


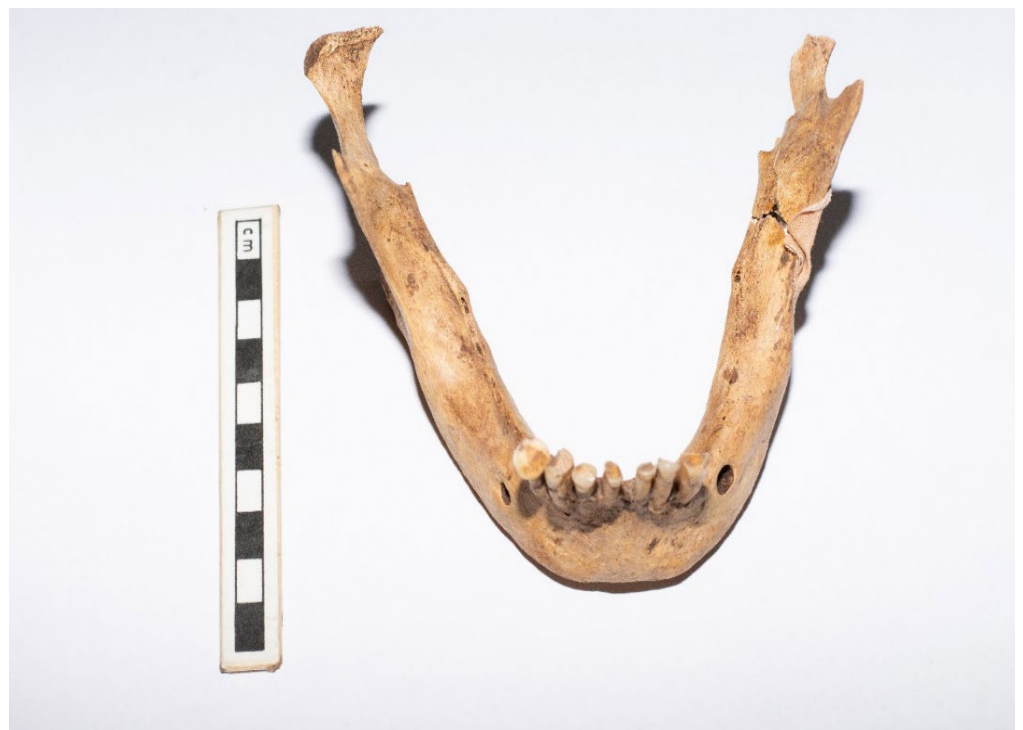

Fig 4 Sealed teeth sockets in the mandible of one of the individuals from the Begho excavation; an indication of ante-mortem teeth loss. (Photo from Lamptey, 2019)

unattractive. This raised the importance of diastema beauty in the community and thus pushed people (young and old) to acquire it.

According to documented oral accounts (Lamptey 2019), the Hani people artificially hit a small knife (sikan-ma) against the incisors to break off parts of the teeth to create space in-between the incisors, disregarding the pains and dangers involved. This artificially created diastema leaves the edges and ends of the teeth (incisors) jagged and slashed due to the crude methods employed. This ethnographic information on the treatment of teeth and perceptions of beauty sheds more light on the jagged edges identified on the incisors of Begho dental arcade. Furthermore, this information associated with jagged incisors highlights the extent to which African skulls and skeletons that were looted from their cultural contexts can lose key and potent interpretations.

\section{Integrating Ethnographic Data to Enrich Cultural Contexts of Human Skeletons}

More revelations often come to light when bioarchaeological analyses are integrated with ethnographic interpretations. Archaeothanatology observations show that funeral complexes and treatments vary considerably based on social, cultural and religious parameters in Africa. Different cultures and religious sects bury the dead differently and these are often reflected in the orientation of skeletons or bones upon discovery. Within these complexes are the issues of ritual as well as practices of primary and secondary burials. Explained within the Begho context, the most common ritual performed during funerals is the pouring of libation and offering of 
prayers to the ancestors and the earth deity ('asaaseyaa'). Other sacred rituals in addition to the holding of a durbar are performed when the deceased is a chief. In this case, he is laid in state in a well-decorated coffin and buried in a grave dug within the family compound or in the palace compound sometimes buried without the coffin. This mode of burying Hani-Begho chiefs within the palace compound is a way of memorializing them and their reign and to prevent them from being looted; in death the skeleton of a chief, king or queen is still highly cherished by the enemies of that state.

Within the Begho context, when a family is confronted with the bad news of death, the onus lies with the family members to give the deceased a befitting funeral ceremony and burial. Unlike today where the bathing and dressing of the body is done by undertakers in the morgue or a funeral home, in the past, this duty was performed by relatives. If the deceased was a female, for example, women relatives boiled water to bathe them and then anoint the bodies with a mixture of herbs like 'Akyeampong' leaves (Chromolaena odorata) and schnapps liquor before laying them in-state. Male relatives would inform the chief and elders of the community and obtain permission to dig the grave/ pit. They also informed and invited family members outside the community. All respondents explained that women in the family mostly do the crying and cooking and also provide the cloths for padding the coffin and dressing the deceased while the men in the family contribute to buy the coffin, sit to deliberate and plan how the funeral ceremony is to be carried out. After the ceremony, they sit to deliberate on the funeral expenditure, settle debts and, if needed, pick a successor as the clan or family head.

The community's way of sympathizing/empathizing with the bereaved family especially when they are not well-to-do/well off, is to contribute to buy a coffin and the young men in the community dig the grave and carry the coffin to the burial site. A member of the community, Mr. Ntem Abraham, explained that though he was young at the time his uncle passed on, he was not allowed to join the team to dig the grave because he was part of the bereaved family who were grieving over their loss.

The social status of a family becomes evident when a member dies, seen both in what goes into the funeral of the deceased as well as how they are buried. For instance, the rich in the community are buried differently from the poor. The poor are often buried overnight or a couple of days after death with low key attendance. The rich on the other hand are often kept in the mortuary for weeks to aid in preparation for the expected high number of well-wishers that will attend the funeral of the rich deceased person. They are often buried in elegant caskets amid entertaining ceremonies. Furthermore, about $90 \%$ of the respondents mentioned that when a fetus or a baby (between the ages of $0-1$ ) dies, it is put in a small pot, locally called 'Kuku'/'Kukuo', together with the placenta and some herbs, particularly 'Akyeampong', and buried in a shallow hole on a midden. Such babies 
are called 'Kuku-mma' or 'Kukuo-mma' meaning 'pot babies'. Similarly, when children between the ages of 1-5 years die, they are put in card boxes padded with cloth and buried either in a midden or anywhere around the house.

Today, Begho is a predominantly Christian community. As such the difference between a Christian and Islamic funeral ceremony and burial is often based on the fame of the deceased as well as the wealth and role played by relatives and the grave goods attached to the deceased. It gets complicated when such evidences are compared with non-Christian Begho cultural lifeways in the $11^{\text {th }}$ to $16^{\text {th }}$ centuries. More often than not, looted skeletons found in laboratory closets and European museums often lack such contextual information on the archaeothanatology of the communities as well as the nature of associated grave goods from where some of the skeletons may have originated. Some of the laboratory skeletons may not have been traditionally buried, such as the traumatizing and agonizing situation that pertains to the skeletons of Shark Island, Namibia. In such cases, the skeletons can be considered as deculturized elements and victims. Being bound by standard ethical practices associated with their handling, bio-archaeologist handling such provenance investigations must accord them some humane sensitivity. The following section assesses the implications of the above statement.

\section{Human Skeletal Analysis and their Ethical Implications}

According to Hunter and Cox (2005: 213) ethics is "a system of values that have implications for all aspects of our lives whether professional or personal" and "an understanding of the science of morals in human conduct." This informs standards of conduct and moral judgement. When linked to the restitution of human remains debate, it is vital to note that "human remains are not just another artefact; they have potency, charged with political, evidentiary and emotional meanings..." (Cassman et al, 2006, 1) and so must be handled with care. How human remains are viewed, excavated, analysed and treated after analysis should be bound within legal and ethical frameworks. Such concerns vary considerably in different parts of the world on regional, societal and individual scales as they reflect their socio-cultural values and beliefs. It is important to note that different societies across time and space attach different sentiments to the issue of exhumation or excavation and to the study of their human remains (Fforde et al, 2002; Roberts, 2009: 17; Scarre, 2006; Tarlow, 2006; Walker, 2000).

Some scholars have noted that the ability to excavate, investigate and study human skeletons is a privilege and not a right (Joyce, 2002). Being given the permit to do so should make the scholar responsible (Joyce, 2002: 102). Nonetheless, in Britain most human remains were excavated or exhumed from land planned for quarrying, construction of buildings/ houses and roads until the need to develop policies for the excavation of human remains were stressed (Roberts, 2009:17). Similar to the above development, human remains of some communities in Ghana 
had to be exhumed (Fig 5) to resolve conflicts that the government encountered with the locales regarding their relocation in connection with the construction of the Bui dam (Apoh and Gavua, 2016).

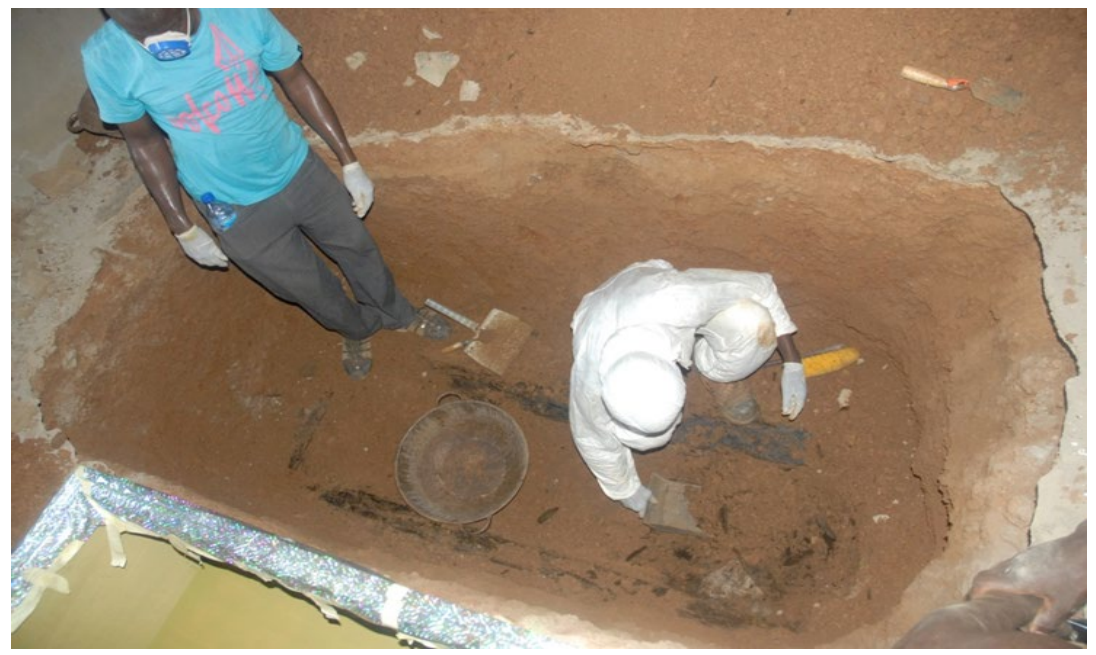

Fig 5 Exhumation of a buried elder of Bui from the room of a descendant to relocate to a new cemetery before the damming of the Black Volta to create the Bui Hydroelectric Power Dam (Photo by Dr Wazi Apoh)

Indeed, there have been debates and suggestions by professionals in archaeology about how human remains should be treated. In Britain, Reeve (1998) provided some clues to ethics regarding excavation and analysis of human remains to include: assessment of potential sites, a statement of objectives, sampling, screening during excavation, basic recording, disseminating of results, taking photographs, display and reinternment (Roberts, 2009: 18). By late 2007, the British Association for Biological Anthropologists and Osteologists (BABAO) sought to draw up a Code of Ethics to provide guidance on the study of human remains. The BABAO's website now has a page devoted to reburial and repatriation (www. babao.org.uk). In 1989, the World Archaeological Congress held an inter-Congress in South Dakota, USA and drew up the Vermillion Accord on Human Remains ${ }^{6}$ that provided guidelines on handling human remains (Roberts, 2009: 18). These were adopted by the World Archaeological Congress Council in 1990.

Some of the guidelines in the accord include elements such as: a) respect must be accorded to all the mortal remains of the dead regardless of race, origin, religion, nationality, custom and tradition; b) respect for the wishes of the dead, relatives or guardians and local community concerning disposition needs to be considered whenever possible, lawfully or reasonably; c) 'respect for the scientific research value of skeletal, mummified and other human remains (including fossil hominids) shall be accorded when such value is demonstrated to exist; d) agreement on

$\overline{6}$ https://www.worldarchaeologicalcongress.org. 
the disposition of fossil, skeletal, mummified and other remains shall be reached by negotiation on the basis of mutual respect for the legitimate concerns of communities for the proper disposition of their ancestors, as well as the legitimate concerns of science and education' and e) the express recognition that the concerns of various ethnic groups, as well as those of science are legitimate and to be respected, will permit acceptable agreements to be reached and honoured ${ }^{7}$.

The complexities inherent in how the remains of the dead ought to be viewed and treated are affected by factors in the realm of belief systems, life experiences and other subconscious and conscious feelings. Religious beliefs do not only determine how a body is disposed of or buried today (Green and Green, 1992), but it also informs on any beliefs in an afterlife. This consequently affects whether it is acceptable to disturb the body by looting, excavating or by collecting and ultimately displaying them in museums (Roberts, 2009: 19).

On the one hand, more recent burials may evoke a sense of direct ownership and relationship with the dead by descendant communities; in that case there could be a strong desire for reburial after excavation and return of remains. On the other hand, much older burials may possess anonymity, especially in cases where the present community is not a descendant community. This development makes excavating, studying and curating more acceptable. For example, Jones and Harris (1998: 258) note that, "if no links can be established with a direct descendant or a group of descendants, then the remains should be available for reputable scientific investigation, since the findings will in the broadest terms be applicable to all humanity" (see Roberts, 2009: 19). Jones and Harris (1998: 258) further notes that: "where the cemetery contains indigenous remains which prove to be the (albeit, usually distant) ancestors of the living population, as in the case of Native American or Australian aboriginal groups, then excavation and analysis may be undesirable and if carried out, reburial should be required with or without analysis" (Roberts, 2009: 19).

Hubert and Fforde (2002: 1) stated that there is an increasing sensitivity and "outward indication of people's sense of identity with their past." In this regard some people are now challenging museums and other institutions' ownership of human remains and demanding that the remains be repatriated and /or reburied according to cultural beliefs associated with the dead (Roberts, 2009: 19). In some cases, even with no genealogical descendants or cultural communities to claim their ancestors officially, groups asserting descent from, or having the best interest of the human remains also make themselves visible during such claims.

However, those who advocate for reburial are not, as Hubert and Fforde $(2002,5)$ put it, "a homogenized undifferentiated whole" sharing the same view. As mentioned earlier in this paper, different cultures view, treat and manage death in varied ways. On a radio programme in the 1970s, Sir Mortimer Wheeler, a prominent

7 Code of Ethics. https://worldarch.org/code-of-ethics/. Retrieved 30/8/2019. 
archaeologist, giving his view on burials in the archaeological record, said, "we do no harm to those poor chaps. When I'm dead you can dig me up ten times for all I care" (Bahn, 1984: 214). Conversely, the inscription on William Shakespeare's gravestone in Stratford-upon-Avon, England reads: “Good friend, for Jesus' sake forbear to dig the dust enclosed here; Bless be the man that spares these stones, and curse be he that moves my bones"; clearly, the Bard did not want his body to be disturbed.

According to Walker (2000), bio-archaeologists ought to adhere to three main ethical concerns regarding analysis or treatment of human remains. These include the respect for dignity ethic, descent ethic and the preservation ethic. Firstly, with regard to the respect for human dignity ethic, he noted that, the remains belong to people who were once living and it is unacceptable to treat them as things or objects because in doing so, one fails to respect the intrinsic human dignity of the people they represent. Second is the descent ethic, which posits that once the remains have been analysed, and biological relations traced to living descendants, the descendant should solely determine how the reburial/reinternment should proceed. And lastly, the preservation ethic posits that some human remains are able to reveal valuable information about a people, and history in general, therefore they ought to be properly curated and preserved for future studies. In summary, Tarlow (2006) notes that, archaeologists have an ethical responsibility to groups of people and the public at large. In view of this bio-archaeologists and museum curators have a responsibility to look after 'our' dead ancestors (Tarlow, 2006). However, it is expedient to maintain a balanced and objective view between human rights, cultural ethics and value judgements (Lackey, 2006).

\section{Conclusion}

The quantity of information that can be gleaned from human skeletons suggests the level of agency inherent in them. With regards to the nature of this bioarchaeological research, the material evidence of the framework of a person after soft tissue decomposition is skeletonization. This exhibits agency in itself, as it is able to reveal vivid details of the bio-history and lifeways of the person. As shown in the Begho case, the grave itself and the grave goods associated with the remains could have agency because such remains of past cultural practices reveal the behavior of the people who buried the dead. This study also offers substantive comparative guidance on any future skeletal analysis being done by archaeologists and how to conceive and process looted African human skeletal remains that are to be returned to their origins.

More importantly, when skeletons are chanced upon in the archaeological record, it is not in every case that they must be collected to the lab for study. In Ghana for instance, before any archaeological excavation and exhumation of skeletal remains can be carried out, permission is sought from the community heads, the Ghana Museums and Monuments Board (GMMB) and the coroner for 
appropriate consent on how to handle human skeletal remains. The permit places a binding responsibility on the excavator to ensure that the skeletal remains are properly excavated, analysed within the right framework and documented in proper context. On-site photos can be taken as well as on-site scanning and recording of artefacts, biofacts and archaeological contexts for further post field analyses. In addition, preliminary analysis can be done by measuring, describing and collecting the essential data that can enable one to determine the bio-history (e.g., sex, age, stature and pathology) of the remains without disturbing them. Certainly, if it is against the wish of community members, no intrusive study should be done.

The archaeologist must comply with the elders of the community to acquire the necessary ritual items for reburial. However, where it is allowed for the human remains to be sent to the laboratory for further studies, be they hominid bones, prehistoric skeletons or skeletons that have no descendant communities, the analyses of the skeletal remains must be done with sensitivity to uphold the human dignity and descent ethic proposed by Walker (2000). Skeletal samples must also be kept under favourable storage conditions and when done with the necessary analysis, they must be returned for a decent reburial.

On the issue of restitution and return of looted, illegitimately acquired, and dubiously acquired African skeletal remains in European museums, we are of the view that they must be unconditionally returned. It can begin with a bioarchaeological provenance study to determine their origins. After which there has to be full disclosure to the source communities about the toxic chemicals used to preserve the remains. And when the descendant communities of such remains are identified, the museum and its government must take all the necessary initiatives to make it possible for the remains to reconnect with their relatives, communities and nations in view of the complex identities that these victims of the past had or have now assumed.

We have to mention specifically here that a number of skeletal remains were also shipped out of Africa by early and recent Euroamerican archaeologists. Most of these were sent out without permit and under the pretense of conducting further scientific studies on them. It is ethically binding on such scholars to return the skeletons to reconnect with their communities. Notably, some Begho human remains were taken overseas for scientific studies by the pioneers of archaeology who worked on the Begho sites as well as other sites in Ghana in the 1960s, 70s and 80 s. Looking at the time that they were collected and sent out, we think that any necessary scientific study should have been completed by now. Thus, it is about time that such skeletal remains are returned for reinternment in their communities in Ghana and, for that matter, Africa. Any associated grave goods or objects as well as the scientific findings and publications derived from the studies must also accompany these. The attainment of collective emotional closure must be the hallmark of our universal fundamental human rights and cultural ethics. 


\section{References}

Anquandah, J. (1995). Archaeological Studies Related to the Slave Trade in Ghana and Implications for Tourism Development. In The Slave Route Project Conference Development of a Cultural Tourism Programme for Africa (pp. 57-64). Ghana: WTTO Conference Proceedings.

Apoh, W. (2019). Revelations of Domination: Discovering the Buried Past of the Akpinis, Germans and British at Kpando, Ghana. Accra: Sub-Saharan Publishers.

Apoh, W. \& Gavua, K. (2016). We will not relocate until our ancestors and shrines come with us: Heritage and conflict management in the Bui Dam Project area, Ghana. Community Archaeology and Heritage in Africa: Decolonizing Practice, 204-223.

Bahn, P. G. (1984). Do Not Disturb? Archaeology and the Rights of the Dead. Oxford Journal of Archaeology 3, 127-139.

Balogh, A. (2019). Eugenics: The Disturbing Skeleton in the Secular Closet http://akosbalogh.com/. Accessed December 14, 2019

Bourdieu, P. (1990). The Logic of Practice. Stanford: Stanford University Press.

Buikstra, J. E (1977). Biocultural Dimensions of Archaeological Study: A Regional Perspective. In Blakely, R. L. (Ed), Biocultural Adaptation in Prehistoric America, Proceedings of the Southern Anthropological Society 11. Athens, GA: University of Georgia Press.

Cassman, V., Odegaard, N. \& Powell, J. (Eds). (2006). Human remains: guide for museums and academic institutions. Lanham: Altamira Press.

Clark, J. G. D. (1972). Star Carr: A Case Study in Bioarchaeology: Reading. Addison-Wesley Modular Publications, 10. London: Addison-Wesley.

Clark, J. G. D. (1973). Bioarchaeology: Some Extracts on a Theme. Current Anthropology 14 (4) 464-470.

Duday, H. (2009). The Archaeology of the Dead: Lectures in Archaeothanatology. Oxbow

Erichsen, Casper W. (2005). The angel of death has descended violently among them: Concentration camps and prisoners-of-war in Namibia, 1904-08. Leiden: University of Leiden African Studies Centre

Erichson, C. \& Olusoga, D. (2010). The Kaiser's Holocaust: Germany's forgotten genocide and the colonial roots of Nazism. London: Faber \& Faber 
Fischer, E. (1959). Begegnungen mit Toten: aus den Erinnerungen eines Anatomen. Freiburg: H.F. Schulz.

Green, J. \& Green, M. (1992). Dealing with the Dead. Practices and Procedure. London: Chapman and Hall.

Hodder, I. (Ed.) (1987). The Archaeology of Contextual Meanings. Cambridge: Cambridge University Press.

Hodder, I. (1992). Symbolism, Meaning and Context. Theory and Practice in Archaeology, 11-23.

Hodder, I. (1999). The Archaeological Process: An Introduction. Oxford: Blackwell.

Hubert, J. \& Fforde, C. (2002). "Introduction: The Reburial Issue in the $21^{\text {st }}$ Century". In Fforde, C. Hubert, J. Turnbull, P. (Eds), The Dead and their Possessions. Repatriation in Principle, Policy and Practice. London: Routledge.

Hunter, J. and Cox, M. (2005). Forensic Archaeology: Advances in Theory and Practice. London: Routledge.

Jacoby, R and Glauberman, N. ed. (1995). The Bell Curve Debate: History, Documents, Opinions. New York: Times Books, Random House.

Jones, D. G. \& Harris, R. J. (1998). “Archaeological Human Remains. Scientific, Cultural and Ethical Considerations". Current Anthropology. 39, 256-264.

Killgrove, K. 2013. Bioarchaeology. In Jackson, J. L. (Ed) Oxford Bibliographies Online - Anthropology. Oxford University Press.

Lackey, D. P. (2006). “Ethics and Native American Burials: A Philosopher's View of Two Decades of NAGPRA". In Scarre, C. \& Scarre, G. (Eds), The Ethics of Archaeology and Philosophical Perspectives on Archaeological Practice. Cambridge: Cambridge University Press.

Lamptey, P. (2019). Contributions of Bioarchaeology to Understanding the Past: A Study of Excavated Human Skeletons from Hani-Begho, Ghana. Unpublished Master's Thesis. Department of Archaeology and Heritage Studies. University of Ghana. Accra, Ghana.

Larsen, C. S. (1997). Bioarchaeology: Interpreting Behavior from the Human Skeleton. United Kingdom: University Press Cambridge.

Larsen, C. S. (2000). Skeletons in our Closet: Revealing our Past through Bioarchaeology. United Kingdom: Princeton University Press.

Posnansky, M. (2015). Begho: Life and Times. Journal of West African History, 1 (2) 95-118. Michigan State University press. 
Posnansky, M. (2010). Reflecting on Begho and Hani, 1970-1998. Los Angeles. Privately Published

Posnansky, M. (2004) Processes of Change: A Longitudinal Ethno-Archaeological Study of a Ghanaian Village, hani 1970-98. African Archaeological Review, $21(1), 31-41$

Posnansky, M. (1970). Discovering Ghana' s Past: Annual Museum Lectures, 1969$1970,18-26$

Roberts, C. (2009). Human Remains in Archaeology: A Handbook (CBA Practical Handbook). Council for British Archaeology, York, UK.

Rubalcaba, J. and Robertshaw, P. (2010). Every Bone Tells A Story: Hominin Discoveries, Deductions and Debates. Charlesbridge.

Selden, S. (1999). Inheriting Shame: The Story of Eugenics in America. New York: Teachers College Press, 1999.

Sofaer, J. R. (2006). The Body as Material Culture. A Theoretical Osteoarchaeology. New York: Cambridge University Press.

Tarlow, S. (2006). Archaeological ethics and the people of the past. The ethics of archaeology: Philosophical perspectives on archaeological practice, 199216.

Walker, P. L. (2000). Bioarchaeological Ethics: A Historical Perspective on the Value of Human Remains. In Katzenberg, M. A. \& Saunders, S. E. (Eds) Biological Anthropology of Human Skeletons. New York; Chichester: Wiley-Liss, Inc. 